Boston University School of Law

Scholarly Commons at Boston University School of Law

Faculty Scholarship

$3-24-2013$

\title{
Dismantling Large Bank Holding Companies for Their Own Good and for the Good of the Country
}

Tamar Frankel

Boston University School of Law

Follow this and additional works at: https://scholarship.law.bu.edu/faculty_scholarship

Part of the Banking and Finance Law Commons

\section{Recommended Citation}

Tamar Frankel, Dismantling Large Bank Holding Companies for Their Own Good and for the Good of the Country, No. 13-05 Boston University School of Law Working Paper (2013).

Available at: https://scholarship.law.bu.edu/faculty_scholarship/843

This Working Paper is brought to you for free and open access by Scholarly Commons at Boston University School of Law. It has been accepted for inclusion in Faculty Scholarship by an authorized administrator of Scholarly Commons at Boston University School of Law. For more information, please contact lawlessa@bu.edu. 


\section{BU School of Law}

\section{Dismantling LARge BanK HOLDING COMPANIES FOR THEIR OWN GOOD AND FOR THE GOOD OF THE COUNTRY}

Boston University School of Law Working Paper No. 13-05

(March 22, 2013)

Tamar Frankel

Boston University School of Law

This paper can be downloaded without charge at:

http://www.bu.edu/law/faculty/scholarship/workingpapers/2013.html 


\title{
D R A F T \\ Dismantling Large Bank Holding Companies
For Their Own Good and For the Good of the Country
}

Tamar Frankel

\begin{abstract}
This paper suggests that bank holding companies are in fact "financial malls." I demonstrates the problems that they pose for the financial system, not only by size but by inefficient and inappropriate concentration. The article suggests restructuring of bank holding companies by introducing more market discipline to the various "shops" in the mall as well as concentrating services for the purpose of efficiency. The Article concludes with suggestion that rather than imposing a restructure by law it may perhaps be possible to entice managements that look to the long-term future to follow a restructure voluntarily.
\end{abstract}

\section{Introduction}

Among the 2008 losses incurred by the various financial intermediaries are the serious losses suffered by mammoth bank holding companies (BHCs). These losses have given rise anew to proposed tightening of bank regulation. ${ }^{1}$ However, there is little agreement on the necessity or the nature of additional regulation. ${ }^{2}$ The suggestion of splitting up Citi, the third largest banking holding company, seems to have been more difficult than the proponents envisioned. The chances of doing that soon are quite low. ${ }^{3}$

These statements do not suggest that only BHCs have caused the financial crisis in 2008. The contributors are far too numerous and the balance of responsibility among them too difficult to compute. ${ }^{4}$ However, whether or not BHCs have contributed their share to the disaster, they cost the citizens of the United States trillions of dollars in "bailouts." To be sure, five years later, in 2013 the treasury is planning to sell most of the TARP banks. ${ }^{5}$ In the meantime the harm was done and has not been repaired as yet.

\footnotetext{
- Professor of Law, Michaels Research Scholar, Boston Unviersity Law School.

${ }^{1}$ See 9 Banks in Major Holding Company Fail, CNNMONEY.COM, Oct. 30, 2009, http://money.cnn.com/2009/10/30/news/economy/fbop_failure/index.htm (last visited June 12, 2012) ("FBOP's banks in California, Illinois, Texas and Arizona bring the number of '09 failures to 115. Depositors insured up to \$250,000.”); Richard W. Fisher and .Harvey Rosenblum, How to Shrink the “TooBig-to-Fail Banks, Wall St. J. A17, March 11, 2013.

2 For a proposal to restructure the regulatory system see Latest CCMR Study Shows Decline in U.S. Share of Global Markets in 2011, PR NEwSwIRE, June 4, 2012, LEXIS, News Library, Curnws File.

${ }^{3}$ Wall Street,l Feb. 21, 2013 C1, C2 (Citi's Chairman, who advocated such splitting is finding it difficult: Deciding who will retain the banking licenses, the funding of a stand-alone investment bank, winding up legal structures of "thousands of entities," notwithstanding the cries of analysts and the regulators to split the giant bank holding company and notwithstanding the fall of its stock and its \$700 billion a year in U.S. government subsidies. Ego and power is much of the glue that keeps these banks together)

${ }^{4}$ The Securities and Exchange Commission was blamed for sleeping at the wheel. TIME Magazine Photos Videos; Sponsored Links Money Fund 2a7 Compliance.

http://www.time.com/time/business/article/0,8599,1843519,00.html\#ixzz24asQsogS

${ }^{5}$ Jefferey Sparshott, U.S. to Sell Bulk Of TARP Banks, Wall Street J. December 18, 2012, at C-3.
} 
I argue that the source of the BHCs' problems is neither lax rules, nor the rules' weak enforcement. Rather, most of BHCs’ problems stem from, and relate to, their structure. ${ }^{6}$ Therefore I propose to restructure BHCs: Their subsidiaries should exchange their shares with the shares of the BHC held by investors. Thus, the general services of the BHCs should become subsidiaries of the BHCs' former subsidiaries and convert into a service company. This company would provide to each of the former subsidiaries the general services that all subsidiaries need, such as accounting, legal advice, preparing prospectuses, communicating with public shareholders, and advertising. Restructuring in this manner can create more efficient and less toxic financial conglomerates, and introduce stronger market controls, which have been sorely missing. Further, this type of structuring should be voluntary. Those who wish to create or recreate a BHC of this sort should be permitted to do so.

The outline of this paper is as follows: Part one examines the nature of BHCs. I observe that most of BHCs reflect the entire or significant parts of, the financial system. They are similar to financial malls. Part two lists the significant and dangerous disadvantages of the existing BHCs model and notes that the regulation of BHCs' risk-taking is ineffective. Part three offers a way to protect this country from the risks taken by the large BHC financial malls. In this part I respond to some possible arguments that question my proposal in defense of my proposal.

\section{ONE: Bank holding companies are not banks}

1. What we call large BHCs are not banks. Some BHCs may hold subsidiaries that function as banks. One BHC, Washington Mutual., owned various types of banks as subsidiaries. Its management aimed for this HBS to become the "Wal-Mart of banking,", until it imploded in a most spectacular and memorable manner. ${ }^{8}$ However, most BHCs are "financial malls," containing a variety of financial "shops" that offer various financial intermediation services. These shops include securities brokers-dealers and underwriters, managers and advisers of mutual funds, trust funds, and wealthy individual, banks proper, insurance companies, creators and sellers of asset-backed securities, and traders for the BHCs' own account, guarantors, traders in securities' collateral held for customers and various instruments of risk exchanges, and more.

2. How are large BHCs financial malls structured? Currently, a BHC owns the financial shops in a mall. It owns the shares of all the shops in the mall. ${ }^{9}$ The BHC collects the revenues from the various shops and raises funds by issuing its securities to

\footnotetext{
${ }^{6}$ I am not the only one who made this observation. See the arguments of Professor Henry Hu in the article by Gillian Tett, Financial Times, The banks that are too complex to exist Last updated, June 7, 2012. 10:19.

${ }^{7}$ See Peter S. Goodman \& Gretchen Morgenson, Saying Yes to Anyone, WaMu Built Future on Shaky Loans, N.Y. TIMES, Dec. 28, 2008, at 1 (quoting chief executive of Washington Mutual stating that "[bank] hope[d] to do to [the banking] industry what Wal-Mart did to theirs").

${ }^{8}$ Robin Sidel et al., WaMu Is Seized, Sold Off to J.P. Morgan, in Largest Failure in U.S. Banking History, WALL ST. J., Sept. 26, 2008, LEXIS, News Library, Wsj File; .

${ }^{9}$ See Lucian A. Bebchuk \& Holger Spamann, Regulating Bankers’ Pay, 98 GEO. L.J. 247, 258 (2010) (stating that in a bank holding company, "[m]ajor strategic decisions are taken at the holding company level, and the incentive pay of the top executives is tied to the share price of the holding company”).
} 
the public. The managements of the BHCs distribute funds to the shops and determine how, and how much, to reward the shops' managers. More importantly, the variety and inter-connectedness of the shops make it difficult for the BHCs' managements to manage their complex and varied shops especially if the shops closely reflect the entire financial system. ${ }^{10}$ The inability to control this mélange of intermediation activities manifests itself, from time to time by enormous risks which the BHCs and their subsidiary shops incur. Thus, BHCs can produce periodically enormous gains and enormous losses. ${ }^{11}$

\section{The structure of large BHCs differs from other types of holding companies.} For example, BHC structures differ from a business mall in which the mall-owners meet the necessary needs and offer the necessary services that all the shops need and the shops in the mall are owned by different persons and organizations. In such a mall the regulators of each shop address the shop management directly. If one shop is a pharmacy, and the other is a restaurant, each regulator addresses the shop managers directly rather than the owner of the entire mall properties.

BHC organizational structure differs from the structure of mutual funds whose advisers own the organization that services each fund, but each fund is owned by investors. These investors determine whether their funds have performed to their satisfaction. These investors can decimate their fund if they are displeased with its performance by redeeming their shares and forcing it to close (unless other investors have a different view of the fund's performance). ${ }^{12}$

BHC structure differs from Vanguard's structure, a unique mutual fund complex, and the largest in the Untied States todate. The difference is worth noting. In the Vanguard mall, the shops - the various funds entities - and their investors -- own the mall, and pay for its services. Thus, each fund owns shares in the service-giver, such as the trading desk, sales force, accounting and legal services, to name a few. This structure is more efficient because it reduces the cost of duplicate service to the investors in each fund.

However, as to performance, each fund "sits on its own bottom." Its performance is judged by its shareholders, not by a holding company management, or the holding company's shareholders. The power to reward a fund's management is vested in its shareholders, rather than in the BHC's management. The funds' shareholders regulate the

\footnotetext{
${ }^{10}$ E.g., BANK OF AMERICA CORPORATION, ANNUAl REPORT 2011, at 20, http://media.corporateir.net/Media_Files/IROL/71/71595/AR2011.pdf (last visited June 12, 2012) (noting that Bank of America Corporation is a bank holding company and financial holding company "provid[ing] a diversified range of banking and nonbanking financial services” through subsidiaries); Lucian A. Bebchuk \& Holger Spamann, Regulating Bankers' Pay, 98 GEO. L.J. 247, 258 (2010) (“Citibank . . . is a subsidiary of Citigroup, which combines traditional consumer and commercial banking with investment banking, wealth management, and alternative investments such as private equity, hedge funds, and structured products.”) (citing Citigroup financials and Form 10-K).

${ }^{11}$ E.g., the J.P. Morgan 2 Billion Dollars (and may be more) losses reported in Wall Street Journal on May 15, 2012 and the moves take to protect its CEO James Dimon. Dan Fitzpatrick \& Joann S. Lublin, J.P. Morgan Moves to Protect Dimon, WALl ST. J., May 15, 2012, at A1, LEXIS, News Library, Wsj File (noting that board still backs CEO and will not strip him of chairmanship).

${ }^{12}$ A closed-end investment company can take a longer time to fail, but it too will fail if the share prices of the fund fall by lower trading and low valuation of the managements' performance. See
} 
funds, whose shares they own. They may usually regulate the funds by redeeming or selling their shares or refusing to buy the funds' shares. In these circumstances both the funds' managements and their owned servicers take notice of the market signals and take steps to change their behavior, or fail-as they should. Needless to say, their failure does not shake the economy nor borne by the country's taxpayers.

\section{TWO: BHC structural model raises serious disadvantages for their investors, and the financial system, against which current regulation does not effectively protect}

\section{The larger BHCs are, the more risk they pose by their interaction with similar} large BHCs. These interbank interaction and interbank markets might create domino effects. The failure of one or few is likely to raise risks for the entire financial system. If even one bad apple is sufficiently larch, such a domino effect can cause the good apples to rot.

One study of financial services' conglomeration noted the interbank markets. To be sure, there are positive values to such markets "for the proper functioning of modern financial systems. However, a network of interbank exposures may lead to domino effects following the event of an initial bank failure." 13 The study reviewed the contagion risk for the Belgian banking system over the period 1993-2002 and found that "an increase in the relative importance of cross-border interbank exposures has lowered local contagion risk" but may have increased the contagion risk brought by foreign banks. ${ }^{14}$ Similarly, in the case of BHCs, while each shop in the mall might benefit from the contagion, each shop may also be exposed to the risks taken by other shops in the mall or by the mall in its entirety.

The current proposed regulations and restructures of large BHCs are ineffective to avoid this domino effect even within one BHC. America's bank supervisors conduct comprehensive inspections of BHCs and assign them a supervisory rating, known as a BOPEC rating. Before 2005, these rating reflected the BHCs' overall condition. ${ }^{15}$ The

\footnotetext{
${ }^{13}$ Hans Degryse \& Grégory Nguyen, Interbank Exposures: An Empirical Examination of Contagion Risk in the Belgian Banking System, INT’L J. CENTRAL BANKInG, June 2007, at 123, 123, www.ijcb.org/journal/ijcb07q2a5.htm (last visited May 17, 2012).

${ }^{14}$ Hans Degryse \& Grégory Nguyen, Interbank Exposures: An Empirical Examination of Contagion Risk in the Belgian Banking System, INT’L J. CENTRAL BANKING, June 2007, at 123, 123, www.ijcb.org/journal/ijcb07q2a5.htm (last visited May 17, 2012) (emphasis added).

15 John Krainer \& Jose A. Lopez, Using Securities Market Information for Bank Supervisory Monitoring, InT’L J. CENTRAL BANKING, Mar. 2008, at 125, 125, http://www.ijcb.org/journal/ijcb08q1a4.htm (last visited May 17, 2012) ("An empirical model of these BOPEC ratings combined "supervisory and securities market information. [The model demonstrated that] [s]ecurities market variables, such as stock returns and bond yield spreads, improve the model's in-sample fit. Debt market variables provide more information on supervisory ratings for banks closer to default, while equity market variables provide useful information on ratings for banks further from default. The out-of-sample accuracy of the model with securities market variables is little different from that of a model based on supervisory variables alone. However, the model with securities market information identifies additional ratings downgrades, which are of particular importance to bank supervisors who are concerned with systemic risk and contagion.”).
} 
evaluation concluded that "the proposed regulations are not optimal in meeting the danger of the domino effect on the financial system."16

2. Bank regulation and regulator fail to control BHC risk-taking. They are not very effective in reducing “deposit-insurance-related moral hazard" such as "cashasset reserve requirements, risk-sensitive capital requirements and deposit insurance premia, and bank closure policy.”17

Moreover, regulators fail to "examine the impact of the competitive environment (bank charter value) and industry structure (scope of banks) on these moral hazards. [They] also examine the implications of banking theory for alternatives to deposit insurance." ${ }^{\text {"In }}$ addition, so long as large BHCs are classified as banks, their regulators are uniquely unsuitable to examine, supervise and regulate all the different types of financial shops in these large BHCs, except the units that engage in banking intermediation. For example, while investment advisers to individuals and mutual funds are regulated as fiduciaries, banks are regulated as contract parties, subject to strict regulation which aims at maintaining the entities "safety and soundness." That is - the more they earn the better regulated they are. Less attention is paid to HOW they earn and at whose account.

\section{Researchers have argued that banks' "underwriting practices are the primary} determinant of bank credit risk and bank credit availability. For this reason, U.S. bank supervisors conduct periodic surveys to assess bank underwriting practices and their level of riskiness. In early 1995 the Federal Deposit Insurance Corporation (FDIC) introduced a comprehensive examination questionnaire, or survey, of bank underwriting practices at FDIC-supervised banks. . . . The survey cover[ed] lending practices both in general and in specific loan categories [and] investigate[d] (1) the relationships between examiners' assessments of the riskiness of bankers' lending practices and subsequent changes in bank condition, and (2) the question of whether these relationships can enhance supervisors' early-warning systems." The investigators found "that higher (lower) risk in underwriting practices is associated with subsequent increases (decreases) in nonperforming assets generally" and "that assessments of underwriting risk contribute to off-site surveillance models that predict safety and-soundness examination ratings. However, this conclusion is largely subsumed by that of concurrent safety-and-soundness examinations ratings. Thus, underwriting survey data are best used as diagnostic measures of the sources of financial distress."19 These measures seem to apply to banks. The question is whether they are appropriate to BHCs.

Bank concentration and bank frailty were examined in 2005. The authors "[found] no support for the view that concentration increases the fragility of banks," but the contrary:

\footnotetext{
${ }^{16} I d$.

${ }^{17}$ Sudipto Bhattacharya et al., The Economics of Bank Regulation, 30 J. MONEY, CREDIT, \& BANKING 745, 745 (1998).

${ }^{18} \mathrm{Id}$, at $745-70$.

${ }^{19}$ John O’Keefe et al., Bank Loan-Underwriting Practices: Can Examiners' Risk Assessments Contribute to Early-Warning Systems? (Working Paper No. 2003-06, 2003), http://www.fdic.gov/bank/analytical/working/wp2003_06/wp2003_06.pdf (last visited May 17, 2012).
} 
"concentration [was] associated with a lower probability that the country suffers a systemic banking crisis. In terms of policies, [they found] that . . regulations [facilitating] competition in banking [were] associated with less -- not more -- banking system fragility and [did not result in] concentration. [They suggest] that concentration is a proxy for something else besides the competitive environment. [Neither did they find] that official capital regulations, reserve requirements, or official prudential regulations lower crises probabilities. [They offered] suggestive evidence that concentrated banking systems tend to have larger, better-diversified banks, which may help account for the positive link between concentration and stability." ${ }^{20}$ It is doubtful whether the praise for bank concentration and related stability would survive the added facts since 2005 and the price that the country has been paying for their concentration.

In September 2007 risk assessment continued to be noted as an important protection against failure of financial institutions. One insurance executive noted: "A thorough assessment of risks and risk management strategies allows the insurance company's risk manager to perform robust analyses to support strategic decisions.” Insurance company risk managers today need to "identify[], assess[], prioritiz[e], control[], financ[e], and monitor[] . . . natural hazards, shareholder lawsuits, ... the theft or destruction of critical data," and other risks that confront the enterprise. The need for a thorough risk assessment to assess profit potential and establish sustainable rates is discussed. ${ }^{21}$ Risk assessment for banks has occupied other researchers as well. ${ }^{22}$ They did, however, note that new "trading products" may require special risk assessment. ${ }^{23}$ A year later, they may have emphasized this point louder. In sum, risk assessment has been occupying both regulators and researchers, but assessments did not seem to have had a preventive effect on the events of 2008.

\section{The regulation of BHCs' mall structure reflects the weakness of their} regulation. Among the mall's shops are institutional intermediaries, such as banks, mutual funds, and insurance companies as well as market intermediaries, such as underwriters and broker-dealers. In addition, BHCs own entities that create securities,

\footnotetext{
${ }^{20}$ Thorsten Beck et al., Bank Concentration and Fragility: Impact and Mechanics (NBER Working Paper No. 11500, 2005), http://www.nber.org/papers/w11500.pdf?new window=1 (last visited May 17, 2012); Thorsten Beck et al., Bank Concentration and Fragility: Impact and Mechanics, in THE RISKS OF FinANCIAL InSTITUTIONS 193 (R. Carey \& R.M. Stulz eds., 2006).

${ }^{21}$ John J. Kollar, Conduct a Thorough Risk Assessment, BUS. INS., Sept. 3, 2007, at 28, LEXIS, News Library, Arcnws File.

${ }^{22}$ Craig Focardi, Recalibrating Loan Risk Assessment, MoRTgAge BANKING, Aug. 1, 2007, at 105 (lenders can improve their profit margins and gain a competitive advantage in spite of slowing home-price appreciation and rising delinquencies by refining their risk-assessment policies and recalibrating their information technology tools. Some of the new tools and approaches that lenders can use to assess the probability of default and other mortgage risks are discussed.).

${ }^{23}$ Curtis Knight \& Francis Garritt, Best Practices for Risk Analysis and Approval of New Trading Products, RMA J., Mar. 2008, at 34 (although risk analysis of new trading products or activities is an often-lengthy process for financial institutions, there are ways to streamline it. In order to ensure that risk is identified, captured, and managed, risk managers must ensure that the objectives and new-product introduction process are transparent and that the appropriate degree of due diligence is conducted. Details are provided on how to streamline the tedious process of careful risk analysis of new trading products or activities, and a table lists business unit responsibilities and market risk responsibilities).
} 
offer guarantees of various types and cover risks of various types. Two main regulators regulate these shops. Their approach, the laws they must enforce, and their views of the functions they regulate, differ significantly.

The focus of the Securities and Exchange Commission (SEC) is on disclosure of market intermediaries and fiduciary duties of advisers to investors. Bank regulators focus on the "safety and soundness" of the banks. While the focus of the SEC regulation is the protection of investors, the focus of the bank regulators is on protection of the banks' safety, and indirectly the protection of the FDIC, which aims indirectly to protect the depositors, which aims indirectly to protect the banks by preventing the depositors' run on the banks. The SEC and the laws it administers are not concerned with the safety and soundness of either market intermediaries or the advisers and managers of mutual funds. If the fiduciaries are less profitable-that is their business, not the regulators' concern. Their focus is on the protection of investors from the possible misappropriation by the people who hold and manage the investors' money. ${ }^{24}$ Enforcement of the law is not necessarily by the SEC. The SEC may perform an investigation or may allow another company to perform an internal investigation. But in that case it will "test and probe and verify to see whether or not that investigation is thorough and independent." 25 Arguably, the SEC is concerned with the investors' trust in the securities markets. To that extent the reputation of a large investment banks or funds may involve the SEC's concern. But even in that case the concern is about the market system rather than the well being or profitability of a particular large fund.

Consequently, the laws, purposes, and interpretational approaches of the two regulating agencies differ in fundamental ways. The regulators of the two types of agencies are differently raised, and trained. They define the regulation's objective and the differently. For example, when a bank regulator supervising the bank's management of trust accounts and mutual funds was asked for the purpose of his supervision he answered that his main purpose was to protect the bank's reputation. Safety and soundness reared its head even in this highly regulated fiduciary law duty area. The regulator of the bank as trustee aimed at protecting the bank's trustee reputation and business. Presumably, the purposes of both regulators coincide to the extent that the benefits to trust beneficiaries and to a trustee bank coincide. But in a case of a conflict, such as when the bank charges beneficiaries more than competitors do and the beneficiaries have no recourse against the overcharge, the bank regulator may seek ways to protect the bank's reputation as well as the banks higher fees and diluted fiduciary duties. "Maintenance of the bank's reputation” is the important regulatory aim.

\footnotetext{
${ }^{24}$ United States Securities and Exchange Commission, The Investor's Advocate: How the SEC Protects Investors, Maintains Market Integrity, and Facilitates Capital Formation, http://www.sec.gov/about/whatwedo.shtml (last visited May 22, 2012) ("The mission of the U.S. Securities and Exchange Commission is to protect investors, maintain fair, orderly, and efficient markets, and facilitate capital formation.”).

${ }^{25}$ David S. Hilzenrath, Probes of Firms Rely on Companies’ Own Legwork, WASHINGTONPOST.COM, May 23, 2011, at A01, LEXIS, News Library, Curnws File (noting also that internal investigations are often conducted by former Department of Justice and SEC employees).
} 
It is interesting that the SEC has received scathing criticisms of its failure to regulate and prevent the 2008 crash $^{26}$ on the one hand, and for its failure to justify its regulation, on the other hand. ${ }^{27}$ Its name is linked to the debacle of 2008. In December 2007, for example, an article headed "Is the SEC a Tough Enough Watchdog?"28 noted that the SEC should "refocus its attention and overcome two key challenges. First, the SEC currently utilizes its valuable resources to ensure that accounting standards are followed. This effort does not seem to leave sufficient resources to enhance disclosures in areas that are critical to investors. The second challenge is that accounting standards have, until recently, centered on historical information. If the SEC is going to achieve its mission of protecting investors by providing valuable information, it also needs to emphasize the quality of disclosures related to forward-looking information." 29 The two conservative members of the Commission today are as vehement about the need to prove beyond any doubt by specific numbers, stories and histories and anything else possible to justify any added rules, regardless of the events that brought about the 2008 crash and regardless of Congressional directives. ${ }^{30}$

In contrast, and surprisingly, one hears little criticism of the bank regulators, even though it seemed that the main drain on the citizens' resources after the 2008 crash was the result of steps taken to save large bank holding companies rather than the small brokers, dealers and even larger underwriters. Needless to say, the government did not support one large investment banker ${ }^{31}$ whose failure may have contributed to the panic of 2008.

Regardless of assigning blame-there is enough to go around-quite clearly the SEC does not have the political support, the power and the money that the bank regulators have. And while the SEC has been suing the large investment banks and investment bankers and brokers that arguably violated the law, bank regulators have not sued even a single bank or banker or bank holding company that received handouts from this country’s citizens to support the holding companies from failing. ${ }^{32}$

\footnotetext{
${ }^{26}$ E.g., Sewell Chan, Financial Crisis Was Avoidable, Inquiry Finds, N.Y. TIMEs, Jan. 26, 2011, at A1, LEXIS, News Library, Curnws File (noting Financial Crisis Inquiry Commission finding that SEC "failed to require big banks to hold more capital").

${ }^{27}$ E.g., Floyd Norris, A Regulator, A Lawmaker, A Quandary, N.Y. TIMES, Aug. 19, 2011, at B1, LEXIS, News Library, Curnws File (noting criticism of "burdensome SEC regulations").

${ }^{28}$ Victor Valdivia, Is the SEC a Tough Enough Watchdog?, CPA J., Dec. 2007, at 24.

${ }^{29}$ Id. at 31.

${ }^{30}$ See, e.g., Mark Schoeff Jr., Schapiro on Political Hot Seat, INV. NEws, May 7, 2012, at 16, LEXIS, News Library, Curnws File (noting expected opposition from Republican Commissioners Paredes and Gallagher to money market reform).

${ }^{31}$ E.g., Carrick Mollenkamp et al., Lehman's Demise Triggered Cash Crunch Around Globe --- Decision to Let Firm Fail Marked a Turning Point in Crisis, WALL ST. J., Sept. 29, 2008, at A1, LEXIS, News Library, Wsj File (noting reasons for Lehman Brothers' demise and that government allowed firm to fail but propped up other firms).

${ }^{32}$ E.g., SEC Enforcement Actions: A Look at 2011 and What to Expect in the Next Year. MoNDAQ, Mar. 5, 2012, LEXIS, News Library, Curnws File (noting recent enforcement actions).
} 
It should be noted that bank regulators have fought to expand bank business for many years. In 1916 a bank regulator demanded to allow banks to issue insurance policies. ${ }^{33}$ After the Glass-Steagall Act prohibition on banks' engagement in the markets, bank regulators have been the best and most ferocious advocates for repealing the barrier. They found ways to expand the banks' market activities abroad when the Supreme Court struck down the Comptroller's permission for the banks to reenter the market intermediation in a somewhat round about way. ${ }^{34}$ Banking could not have and does not have today a better advocate, lobbyist and sales organization than their regulators.

In sum, banks' regulation and the securities market differ in purpose and regulatory focus. The SEC's center of attention is the secondary and primary securities markets. ${ }^{35}$ Bank regulators concentrate on the financial money markets and money supply. ${ }^{36}$ While bank regulators focus on the banks' investments and their financial stability, the SEC has been focusing more intensely on the broker dealers and sales offices services to investors. ${ }^{37}$ While securities acts mandate the protection of investors by disclosure and intermediaries duties for the protection of investors, bank regulation aims first and foremost at the protection of banks' "safety and soundness," which indirectly leads to the protection of the FDIC, which is designed to protect the depositors, and preventing the depositors' run on banks.

\footnotetext{
${ }^{33}$ Letter from John Skelton Williams, Comptroller of the Currency to Sen. Robert Owen, reprinted in 53 Cong. Rec. 11,001(1916), cited in Scott A. Sinder, The Gramm-Leach-Bliley Act and State Regulation of the Business of Insurance, Past, Present and . . Future?, 5 N.C. BANKING Inst. 49, 56 (2001).

${ }^{34}$ Investment Co. Inst. v. Camp, 401 U.S. 617 (1971); Frederick W. Gerkens, Note, Opportunities for Regulatory Arbitrage Under the European Economic Community's Financial Services Directives and Related United States Regulations, 16 N.Y.L. SCH. J. INT'L \& COMP. L. 455, 460 (1996) (noting that "Federal Reserve Board ... . Regulation K has been relaxed to expand the scope of permitted banking activities abroad”); Regulation K, 12 U.S.C. pt. 211 (2012) (governing international banking operations). ${ }^{35}$ United States Securities and Exchange Commission, The Investor's Advocate: How the SEC Protects Investors, Maintains Market Integrity, and Facilitates Capital Formation, http://www.sec.gov/about/whatwedo.shtml (last visited May 22, 2012) (“The mission of the U.S. Securities and Exchange Commission is to protect investors, maintain fair, orderly, and efficient markets, and facilitate capital formation.”).

${ }^{36}$ See United States Federal Reserve System, The Federal Reserve System: Purposes \& FunCTIONS 1 (9th ed. 2005), http://www.federalreserve.gov/pf/pdf/pf_complete.pdf (last visited May 21, 2012) (duties of Federal Reserve include conducting monetary policy, regulating banking institutions to ensure safety and soundness of banking and financial system, and maintaining stability of financial system).

${ }^{37}$ Rachel McTague, Risk-Based Examinations to Look More Often at Brokerage Sales Offices, SEC Official Says, 83 Banking Rep. (BNA) 755 (Nov. 15, 2004) ("Banking Report Volume 83 Number 18 (Risk-Based Examinations to Look More Often at Brokerage Sales Offices, SEC Official Says The Securities and Exchange Commission's examinations staff will inspect broker-dealer sales offices more often under its new risk-based system, John Walsh, chief counsel in the SEC's Office of Compliance Inspections and Examinations (OCIE), said Nov. 5. ("Speaking at an American Law Institute-American Bar Association conference on life insurance company products, Walsh said that the staff will continue to conduct surprise exams, '"particularly of those sales offices.'" In October, Lori Richards, director of OCIE, said that the risk-targeted, in-depth examinations conducted by SEC compliance staff in the past year have yielded a greater number of referrals to the agency's Enforcement Division.”).
} 
Expanded bank services and relaxed regulation went hand in hand. As noted, while the regulation of the markets is based mainly on disclosure, the regulation of the institutional investors is based mainly on substantive regulation. And yet, when the market door opened to these institutions the assumption was that substantive regulation should be reduced. The "market will take care of problems." Indeed it did.

4. Large BHCs defy effective management for two reasons. BHCs are complex, varied, and engaged in financial transactions around the globe. Risky transactions are therefore hard to identify in time. In addition, BHCs' managements are subjected to conflicting pressures. One source of BHC financing is bank deposits, insured by the government and subject to restrictions on banks' risk taking. Its other source of financing is the BHC investors. They demand "performance," which might involve higher risks.

In 2004 it was suggested that the culture of large banks is unique: "hierarchical, bureaucratic and slow-moving organisations (sic) dominated by a 'silo' mentality in which individual units look to their own political interests rather than that of the bank as a whole.” The banks focused on not only the customers' needs but on maximizing the bank's profitability by providing an integrated service package to the clients. ${ }^{38}$ These banks were pressed to meet their investors' demands for higher revenues. This pressure may raise "the likelihood of unethical or unwise credit or market risk judgements.(sic)"39 It may drive banks to finance companies such as Enron, which failed.

In addition "managing size and complexity has become a key management issue as institutions like Citigroup and HSBC, with hundreds of thousands of employees and hundreds of operating units across the globe, have become a new model of universal banking." Of the nine selected large banks that researchers examined, four believed they were truly committed to the clients' interests. ${ }^{40}$ However, that was in 2004.

In 2008 it transpired that conflicts of interest and other issues arose in such banks as well. The researchers concluded: "Sadly, we believe that the pressures from competitors, investors, and internal resistance to change will limit to a small handful the number of banks which can truly lay claim to the status of one bank built around a culture of customer service." ${ }^{41}$

In fact, there is a raging bloodletting current debate on whether and to what extent BHCs should be allowed to trade in the securities markets for their own account. The "Volker Rule” would prohibit or limit such trading. BHCs' managements and some regulators vehemently object. ${ }^{42}$ Until the beginning of 2013, the Volker Rule has remained a

\footnotetext{
${ }^{38}$ Steven Davis, Culture in Banking, AcCounTANCy IRELAND, Oct. 2004, at 15, 15, http://www.dibc.co.uk/culture_in_banking.pdf (last visited June 12, 2012).

${ }^{39}$ Id. at 16.

${ }^{40} \mathrm{Id}$.

${ }^{41} I d$. at 17.

${ }^{42}$ The Dodd-Frank Wall Street Reform and Consumer Protection Act, Pub. L. 111-203-H.R. 4173, signed into law on July 21, 2010. The rule prohibits proprietary trading not at the request of clients. The rules has not been enforced by January 1 2013; Edward G. Eisert* As Volcker Rule Implementation Lumbers On Some Practical Considerations Orrick, Herrington \& Sutcliffe LLP, eeisert@orrick.com
} 
directive to the regulators to be implemented, but has not been put in effect. The fact that $\mathrm{BHC}$ and their regulators are fighting so hard against it helps evaluate the rule's reduction in the benefits and power of the BHC management and their regulators. When the door to money from market investors is shut, so will the power.

Similarly, the Frank-Todd Act tightened the provisions of section 23A of the Banking Act, which limited bank interaction with affiliates. However, the beginning of the year 2013 saw no guide by the Federal Reserve Board on how to implement the congressional directives. It seems that the congressional act is a dead letter until the Federal Reserve Board provides the guidelines.

5. Would the human side in BHC fare better or as importantly as the attention paid to risk management? In The Human Side of Risk, the authors noted: "The key to managing financial reporting exposures often lies" in the people who implement the controls. "The best-designed, best-operated, most flawless control” is only as good as the employee who implements it. Problems occur when the employee does not know--or perhaps even care--how to operate the control; does not read the output correctly; or deliberately manipulates the financial report's findings. In order to stop these problems from occurring, internal auditors need to pay close attention to the "real-world actions ... . taken by real-life employees in addressing the day-to-day duties of their jobs.” Advice is provided for internal auditors on identifying, assessing, and addressing the human element of risk as it relates to financial reporting. ${ }^{43}$

After the crash of 2008, attention and consideration of this aspect of bank regulation has risen. Banks, it was discovered, are organizations that consist of people. The banking institutions are mere organizations that function as well or as badly as the people who manage them and work in them. The regulation of large BHCs reflects the structure of these entities that is the relationships among the managers and people who work there.

As noted, among the mall's shops are both institutional intermediaries, such as banks, mutual funds, and insurance companies, as well as market intermediaries, such as underwriters and broker-dealers, as well as entities that create securities, offer guarantees of various types and cover risks of various types. When the incentives of the actors are skewed; when they receive bonuses on short-term rising market prices; when they are not controlled in their risk-taking and encouraged to produce "untested innovations," they will be driven to churn the markets, to take high risks with other people's money, and to forget that they are risking the citizens' money.

In fact the people who managed and lost other people's savings did not withdraw from management. They blamed others for the plight of the country. ${ }^{44}$ These attitudes tell us

\footnotetext{
43 Russell Jackson, The Human Side of Risk, InTERNAL AUDITOR, Oct. 2007, at 38.

${ }^{44}$ See, e.g., Charles Riley, Dimon: JPMorgan Traders Didn't Understand Risks, CNNMONEY.COM, June 12, 2012, LEXIS, News Library, Curnws File (noting that CEO planned to blame loss primarly on "personnel and activities of the chief investment office").
} 
something about their view of their own obligations and responsibilities and the effect of the exercise of power or self-restraint and honest self-evaluation.

Part four. What should be done to protect the country from the risks taken by the large BHC malls? What solutions will this proposal offer?

1. A proposal. I propose to eliminate the concentrated management power of BHCs and raise their investors' power and market judgment. We can retain the benefits of BHCs and eliminate their disastrous effects. To reduce duplication, let the holding company become a servicer to its current subsidiaries. In addition, if collaboration among the various units is beneficial, such as offering investors combined services to a "full service” package, this collaboration should be facilitated and legal.

Let the shareholders of each subsidiary (shop in the mall) choose its management, judge its performance, and regulate it by market forces. The subsidiary may be a bank, a mutual fund or an underwriter. Let the bank in the BHC mall be regulated as the bank outside the mall is being regulated. Let any other financial shop in the mall be regulated by the appropriate regulator free of the influence of other regulators.

\section{The benefits of restructure}

First, a restructured $B H C$ resolves the issue or reduces the danger of the few BHCs that are "too big to fail." The failure of these BHCs poses a threat to the entire financial system. The chance of failure of all the shops in the mall is far lower than the chance of failure of the holding company, especially since each shop is engaged in a different, and sometimes competing financial intermediation. The problem of conflict of interest within the BHC current structure will be reduced to a great extent, as each unit tends to compete with the other. The problem of faulty controls over the various units in the BHC will be reduced or resolved since the units will be more homogeneous and smaller, and therefore easier to control and manage. The problem of concentrated and toxic power currently in the BHC will be resolved by competition and cooperation on the issue of services.

This solution also helps resolve or reduce the problem of managements' control limitations. There comes a point when the "too big to fail" is truly "too big to manage." Breaking up BHCs into their unique services allows for a far more effective management, not only in risk controls and prudent innovations, but also in profitable services. It facilitates focusing on investors' and customers' needs and balances the two groups' desires. It helps create an appropriate service culture within each unit and the service organization as well. Restructuring the BHCs is likely to open the door to a more effective market discipline over each of the shops in the BHC financial mall. Most importantly, restructure might help encourage more diverse and less concentrated regulation, vesting power in regulators who know more about specific parts of the financial system rather than concentrating on their view of non-fiduciary banks. 
Second, a restructured BHC facilitates and increases the markets' regulation. Our Congress and regulators have moved the financial system to the markets in the belief that markets judge the performance of financial intermediaries and regulate them better than government regulators. This belief may be questioned, but it is still deep in the bowels of the banks, of many regulators and legislators. If so, and if we believe that banks should be the mall of the financial system, let us give the shops in the mall direct access to the markets, and most importantly, let the markets have direct regulatory power over the shops in the mall.

To be sure, this proposal is based on faith in the markets. In this case, performance and honest management are two aspects which the market investors, whether individuals or institutions, would watch for. Therefore, allowing market participants to examine the determine the value of each shop in the BHC mall avoids some of the difficulties and conflicts of interest that directors and officers of the large bank holding companies may be experiencing.

Even if the service company's directors and officers hold a sway over the shops in the mall, their influence will be reduced by additional directors, the markets' judgment and the information that market participants may find easier to digest. After all, information about each shop will be less complex and far more informative than the information of all shops bunched together under the umbrella of a BHC.

Will the amount of available information about a restructured $\mathrm{BHC}$ be greater? Will information cost more and too much? The answer is: Perhaps; but not by much. Mutual fund advisers, who manage many funds, do well even though they must disclose the information about each fund separately. ${ }^{45}$ With the development of on-line information, its cost is falling and is very likely to continue to fall. Besides, the shops produce information that the BHC is currently providing the public investors. When information about the BHC is less important, it can be reduced and compensate for the information about each of the former subsidiaries of the BHC.

Third, this proposal reduces the enormous power-concentration of BHCs' managements and its regulators. Let us reverse the power structure. The time has come to reduce it. Bank holding companies and their management will have no power over any of the various financial services in the mall. The units of these financial services, be they banks, insurance companies or mutual funds and broker-dealers, will have to raise their funds in the markets and enable the markets (not the managements of the BHCs) decide who performs better. In addition, restructure will be easier to introduce some barriers of conflicts of interest. Competition among the various shops in the mall, even if not compete, may reduce collaboration that produces so much conflicts of interest. ${ }^{46}$

\footnotetext{
${ }^{45}$ See Tamar Frankel and Ann Schwing, The Regulation of Money Market Funds@

${ }^{46}$ Even though the restructure will not effectuate the Volcker Rule entirely, it may introduce incentives to follow it without regulation. Dodd-Frank Wall Street Reform and Consumer Protection Act, Pub. L. No. 111-203, sec. 619, § 13, 2010 U.S.C.C.A.N. (124 Stat.) 1376, 1620-31 (codified at 12 U.S.C. § 1851 (Supp. 2011)) (Volcker Rule) (generally prohibiting banking entities from engaging in proprietary trading or having ownership interest in or sponsoring hedge funds or private equity funds) (generally effective 12 months after issuance of final rules or July 21, 2012).
} 


\section{A number of serious contrary arguments to the proposal should be addressed}

First, what if each mall elects the same directors? After all, the first directors are usually chosen by the promoters, and thereafter, by the management whom the directors engage? That, indeed, may be possible. However, unlike initial entities that have come into existence by a promoter, in this case the units are already established, have personnel, a business, and shareholders will receive participations in ongoing concerns. Therefore, it may well be that the existing managers will induce shareholders to maintain their own position, which in this case may mean continuity. The market prices of their shares, however, may direct the units' future performance. In fact, the breakup of a BHC colossus will create viable units, in contrast to units that have to be established. It is a unique initial public distribution of entities with business history.

Second, arguably credit costs will rise with the dilution of the synergies from affiliates within a BHC structure. Perhaps! Yet affiliates within the BHC may offer chances for increased availability of sharing permissible information, while competing. In addition, as we have seen, arising from the rubble of too much credit offered to people who cannot afford to pay back their loans, there is a limit to the good that synergies may bring. Today, some synergies have been so intense as to destroy our financial system. Therefore, let us wait until the dust settles, and then find out whether there is a need for more credit and to whom. In addition, the BHC, in its position as a service company, can offer all the synergies that the various parts of the BHC mall and especially the banking part, need. In fact, the combined services may save the costs and reduce some of the duplication that is now practiced in the BHC. The new structure may reduce the "synergy" that is bringing confusion and complexity to BHC management.

In addition, we may discover the extent to which the synergies under the new proposed structure are missing, and complement them by safety measures for the bank part of the mall. For example, the safety, which might be provided by the upcoming Basel III and other new capital requirements, could then be increased. However, these requirements have met with strong objections. ${ }^{47}$

My answer is that there are doubts whether the Basel III measures will pass, and if they do how much good they will do. Thus, these alternatives may be welcome for the banks but not necessarily contradict the conversion of the BHC into a service company, owned by all the shops in the mall.

Third, imagine a possible post-break-up scenarios. Is it possible that certain business lines currently ensconced in BHCs might not survive as stand-alone entities? What if bank lending that is often used as a marketing tool to get more lucrative I-banking

\footnotetext{
${ }^{47}$ E.g., Deborah Solomon, Regulators Wrangle on Rules --- Geithner and EU Counterpart Diverge on Bank Capital, Compensation Caps, WALL ST. J., June 3, 2011, at C3, LEXIS, News Library, Wsj File (noting "intense behind-the-scenes lobbying by some large financial institutions opposed to any additional capital requirements").
} 
business will shrink or disappear? ${ }^{48}$ If traditional commercial banks must stand alone, what would banking services look like? What if private securities offerings would become cheaper than traditional lending by newly stand-alone banks? That might doom those standalone entities and raise borrowing costs.

The answer to these arguments, based on possible scenarios, is that BHCs are not the only ones that offer bank services. There are $1352^{49}$ stand-alone banks in this country and some are doing quite well. In fact, they are doing better than the BHCs colossus. To be sure, some banks are failing. But their failure does not shake the entire financial system. There are only some banks within the BHC. ${ }^{50}$

Even if all their banking business disappeared, it is unclear that their service will be substituted by market private placement and that private placement as a source of credit is a bad alternative to some banks. It is more likely that other, new and fresh, banks will arise and serve better.

Fourth, look at the successful and desirable vertically integrated auto manufacturers, energy firms and others! Why not aim at the same model for BHCs?

I have no answer to this argument because I am not an expert in complex corporate management. All I can say is that the new structure should not preclude cooperation and joint ventures among the various units in the restructured complex. The suggestions can come from the units or from the service company or from outsiders. The restructure does not and should not preclude such cooperation.

Fifth, arguably, if and so long as risks are appropriately segregated within the BHC subsidiaries, why is the restructure of the BHC better? Even if BHCs rely too heavily on intercompany financing within the BHC, and contaminating good asset pools with the liabilities of bad asset pools, why not address the issue more directly, with targeted regulation?

This argument is powerful, but not as convincing as it looks. Most rules are not as strong as structure. Self-interest is too often stronger than rules that attempt to overcome it. Habits and patterns of behavior make it hard to change by rule. Large BHCs did not

\footnotetext{
${ }^{48}$ Chuck Whitehead tells me that lending profits at commercial banks are razor-thin these days,

${ }^{49}$ Michael White/Meyer-Chatfield Report 3Q YTD BOLI Assets Continue to Climb, Favoring Hybrid Accounts, ABIA Ins. NEws, Jan. 25, 2012, http://www.aba.com/NR/rdonlyres/023BD09C-8647-40AB863A-55656D272CDE/74838/ABIA_Newsletter_Jan_25_12.pdf (last visited May 24, 2012) (noting that “[m] sost banks are subsidiaries of bank holding companies"; of 6740 commercial banks and FDICsupervised savings banks, 1352, or 20.1\%, are stand-alone banks).

${ }^{50}$ See Michael White/Meyer-Chatfield Report 3Q YTD BOLI Assets Continue to Climb, Favoring Hybrid Accounts, ABIA INs. NEws, Jan. 25, 2012, http://www.aba.com/NR/rdonlyres/023BD09C-8647-40AB863A-55656D272CDE/74838/ABIA_Newsletter_Jan_25_12.pdf (last visited May 24, 2012) (noting that “[m] ost banks are subsidiaries of bank holding companies”); Lucian A. Bebchuk \& Holger Spamann, Regulating Bankers' Pay, 98 Geo. L.J. 247, 258 (2010) (“The biggest banks in the United States . . are not stand-alone entities, but . . . bank holding companies ....”).
} 
arise in a day and limits on risk did not flower quickly. In fact, they are flourishing today. Therefore, unless there is a structural change supported by market pressures, the chances are that people's interaction, favoritism and fixed beliefs will overcome regulation and may make it increasingly harder to enforce. Moreover, innovations are the darlings of American culture, and even if they start by moving in the right direction they may end in a slippery slope, culminating in a disaster that can destroy our economy.

An example of this type of regulation is Rule 3a-7 under the Investment Company Act. ${ }^{51}$ This Rule allowed the designers of asset-backed securities to establish an entity that is part but not fully a mutual fund. Unless the entity which hold the loans that form the basis of the issued securities was exempt from the regulation of the Investment Company Act of 1940 they could not achieve the securitization goal. Therefore, after many examinations and individual exemptions the Securities and Exchange Commission promulgated a rule that exempted the Special Purpose Entities or Special Purpose Vehicles (SPVs), as they are called, from the applicability of the Act. The rule is long and detailed, designed to distinguish between the mutual funds and the SPVs. However, the rule exempted the SPVs from section 12(d)(1) of the Investment Company Act. ${ }^{52}$ This section prohibited, with a very limited exemption, the creation of funds of funds of funds.

The serious problem posed by these pyramids was noted in the 1920s and clearly described in the preamble to the Act; ${ }^{53}$ hence, the prohibition in section $12(\mathrm{~d})(1)$. I maintain that one of the reasons for the worse losses and confusion of the asset-backed securities was the design of SPV pyramids. These SPVs accepted parts of the assets of other SPVs and issues securities based on these asset parts. Then innovators established other SPVs that accepted parts of assets of the second SPVs and caused the issuance of securities. There could be new SPVs that acquired parts of the assets of the second level SPVs that then issues securities. These SPVs of SPVs of SPVs produced numerous securities based on parts of the assets of parts of the assets of parts of the assets of the first SPVs that were the actual loans. Not only were there thousands of securities based on others, but they were based on nothing but others that held loans. The structures made it difficult to find out who owns what? A stream of income does not function by itself. It is made by people. In this case you have no idea who owes and promised to pay, the stream of income becomes anonymous, and little can be done when the promised stream of income dries up.

This innovation was not prohibited, and thereafter no one shut the door for further innovations that no one would have permitted. Hence-good exemptions can become toxic. That is why we cannot rely on them alone. That is why a clear and understood structure must complement the rules. It is not as flexible as rules are.

Sixth, generally, what is wrong with the current situation? Some banks operate solely as traditional lenders. Even if they're held as BHCs, they are not managing hedge funds

\footnotetext{
5117 C.F.R. § 270.3a-7 (2011).

5215 U.S.C. $\S 80 a-12(d)(1)(2006)$.

5315 U.S.C. $\S 80 \mathrm{a}-1(\mathrm{~b})(4)$ (2006).
} 
on the side. If markets value this current structure more, won't those types of entities have advantages over the proposed bank structures?

My answer is that if the financial system were our playground I would like to try and use one existing structure and play it against a proposed new structure and examine the results. In fact, we might use games on the Internet that offer virtual life to discover the results. However, neither the games nor experiments can give us a reliable answer. Changes do not occur overnight; and their results must be tested. Our purpose is to reduce risk in playing with other people's money. Our purpose is to change the BHCs' culture and managements at the least cost. If so, then we must try to do that and examine the result as we go along and refine the results as their flaws may emerge. The one thing we should not do, in light of our recent experience, is to maintain the structure and culture of BHCs as they are today.

Assuming that the proposed structure has to be changed, how should it be done? The regulators can command the restructure. Yet, dismantling huge organizations by outside command of regulators may not be optimal. In fact, when we examine past such commands they were done when the entire financial system was in shambles as it was in the 1920s and 1930s, and even then the structures were produced by negotiations between the government and the financial intermediaries such as the investment companies. Today the financial intermediaries including BHCs are far stronger and command the support of their regulators and significant part of Congress. Therefore, the chances of a restructure by law or regulators' orders are slim. I believe that a change in the law is unnecessary. Restructure should be voluntary.

In addition, the proposed restructure of a BHC can be achieved without a change in the current law or with minimal change (relating ot the service company). If a new such structure arises it can be established under the existing law and the bank regulators, the SEC and insurance regulators cannot legally prohibit the structure if the promoters comply with the current law. There is a need for a law that would prohibit such a structure to be passed. There is a slim chance for the passage of such a law.

Thus, from a legal point of view the conversion is not as difficult as it might seem. Because the BHC holds the shares of each unit in the BHC-colossus, each shareholder of the $\mathrm{BHC}$ can receive a pro rata share of the units held by the BHC and these shares can be traded as the BHC shares were before the distribution. Internally, each unit will receive a pro rata share of the service company which the BHC will become.

Seventh, there is a slim chance that a new entrepreneurial drive of BHC managements would press for a restructure. BHC managements seem to drive for a larger size of the enterprises. Even those who are not eager to manage large financial intermediaries are less eager to announce their more limited ambition. The FDIC and bankruptcy courts may have an impact on the restructure of some BHCs. ${ }^{54}$

\footnotetext{
54 See Dodd-Frank Wall Street Reform and Consumer Protection Act, Pub. L. No. 111-203, §§ 201-217, 2010 U.S.C.C.A.N. (124 Stat.) 1376, 1442-1520 (codified at 12 U.S.C. §§ 5381-5394 (Supp. 2011)) (FDIC orderly liquidation authority); id. at § 202(c)(1), 2010 U.S.C.C.A.N. (124 Stat.) at 1447 (codified at 12
} 
Yet, the purpose of this proposal is not to wait until all BHCs pose danger to the financial system or fail at an enormous cost to the shareholders and the country. The purpose is to find a way to induce and produce such a restructure to prevent the failures. One source of inducement to restructure is the shareholders of the BHCs. That is especially so when the shareholders are institutions that hold significant number of BHC shares. There are situations, especially after the crash of 2008, in which large shareholders have managed to impose some changes on BHCs. However, these changes were usually in the form of personnel changes and the induced departure of the chairman of the board or the Chief Executive officer. ${ }^{55}$ There is a BHC, such as Citibank, that is divesting itself of some shops in its mall. ${ }^{56}$ There are other BHCs, such as Bank of America, which has gone the other way and acquired Merrill Lynch to its mall, ${ }^{57}$ and Wells Fargo, which has acquired Wachovia Bank. ${ }^{58}$ Neither has changed the power structure that is concentrated in the BHC.

Eight, it is unclear whether all shareholders of all BHCs will rise to change their structure. Why should anyone who holds a significant power over billions of dollars give it up to become subservient to those whom he or she managed before? At first glance it would seem that the answer is: No one, especially no one who has managed the colossus before. If power is what the managers enjoy then the new proposed structure would mean to give that power up. There are however, two situations in which such restructure may occur. One is after a BHC has demonstrated danger to the system. In such a case the FDIC has the authority to restructure the entire complex. ${ }^{59}$

U.S.C. § 5382(c)(1) (Supp. 2011)) (applying Bankruptcy Code to bank holding companies other than companies covered under liquidation authority for which FDIC has been appointed as receiver); id. at 202(c)(1) (codified at 12 U.S.C. § 5382(c)(2) (Supp. 2011)) (applying .liquidation authority provisions to bank holding companies covered under liquidation authority for which FDIC has been appointed as receiver).

55 See, e.g., Pallavi Gogoi, BoA CEO Lewis Plans to Step Down; Bank Under Fire from Merrill Lynch Deal, USA TODAY, Oct. 1, 2009, at 1B, LEXIS, Newes Library, Arcnws Library (noting that shareholders voted for CEO’s departure and departure was “hailed” by shareholder First American Funds).

56 See Citi, 2011 ANNUAL REPORT 33, http://www.citigroup.com/citi/investor/quarterly/2012/ar11c_en.pdf?ieNocache=141(last visited June 12, 2012) ("Key divestitures in 2010 included The Student Loan Corporation, Primerica, auto loans, the Canadian Mastercard business and U.S. retail sales finance portfolios.”); id. 153-55 (summarizing divestitures in 2009, 2010, and 2011); CITI, 2010 ANNUAL REPORT 178-81, http://www.citigroup.com/citi/investor/quarterly/2011/ar10c_en.pdf?ieNocache=687 (last visited June 12, 2012) (summarizing divestitures in 2008, 2009, and 2010).

${ }^{57}$ BANK OF AMERICA, ANNUAL REPORT 2010, at 1455, http://media.corporateir.net/media_files/irol/71/71595/reports/2010_AR.pdf (last visited June 12, 2012) (noting Jan. 1, 2009 acquisition of Merrill Lynch). WELls FARGo \& CO. ANNUAL REPORT 2008,,at 100, https://www.wellsfargo.com/downloads/pdf/invest relations/wf2008annualreport.pdf (last visited June 12, 2012) (noting Dec. 31, 2008 acquisition of Wachovia).

${ }^{58}$ WeLls FARGO \& CO. ANNUAL REPORT 2008, at 100, https://www.wellsfargo.com/downloads/pdf/invest_relations/wf2008annualreport.pdf (last visited June 12, 2012) (noting Dec. 31, 2008 acquisition of Wachovia).

59 Dodd-Frank Wall Street Reform and Consumer Protection Act, Pub. L. No. 111-203, §§ 201-217, 2010 U.S.C.C.A.N. (124 Stat.) 1376, 1442-1520 (codified at 12 U.S.C. §§ 5381-5394 (Supp. 2011)) (FDIC orderly liquidation authority). 
In addition, if a manager seeks not only power over others, but also the power of beginning something new and more prosperous; if a manager seeks leadership of a structure which governments and perhaps other managements and regulators would follow, a structure which demonstrate solutions to so many problems without legislation and new added regulation. A leader, who fights regulation, can then show that the markets and the management can solve the problems without government interference. Then perhaps one or two such leaders will arise and demonstrate how this structure can lead to a different and far more stable and successful BHC. Initiative to establish such a BHC should come from the private sector rather than be imposed by law or regulation. Investors should flock to this structure, if well explained. I hope there are entrepreneurs who would try and investors who might be interested. I see that the new CEO of Citi is attempting to change its structure. ${ }^{60}$

\section{Finally, do we need to resurrect the Glass Steagall Act?}

This question arises almost instantly when one views the proposed structure. Yet the answer is not necessarily limited to the Glass Steagall Act. It may well be that future laws should focus not on the units' functions but on the relationships between and among different types of financial intermediaries. It may well be that the next legal issues will involve the issues of cooperation - relaxing prohibitions on antitrust activities. ${ }^{61}$ Or the problems might arise in areas that we do not now envision. Regulators should follow rather than impose their particular view of structures. They should focus on problems that arise from new structures and should follow the operations of the structures and the problems they pose. Regulations and law in general should analyze and focus on problems and their solutions. The problems may arise from new beneficial structures as well as from old ones.

\footnotetext{
${ }^{60}$ Susanne Kapner, Citi’s CEO Is Keeping Score, Wall St. J. March 5, 2013. at C1 C-2.

${ }^{61}$ Barring an exemption, the antitrust laws are applicable to banking. See, e.g., United States v. Phila. Nat'l Bank, 374 U.S. 321, 337 n.12 (1963) (banking is “commerce” under the Clayton Act); Credit Suisse Sec. (USA) LLC v. Billing, 551 U.S. 264, 270, 275 (2007) (in the securities law context, courts must decide "whether . . . there is a 'clear repugnancy' between the securities law and the antitrust complaint," or "whether the two are "clearly incompatible."); 15 U.S.C. § 19(a)(1) (prohibited interlocking directorates and officers does not apply to "banks, banking associations, and trust companies.”);

See also 12 USCS $\S 1467 a(e)], 12$ U.S.C. 1828(c)), (1842) (with exception relating to 12 USCS $\S$ 1843(k)] and 12 USCS $\S 1842$; A joint venture could be a violation of the antitrust laws as a "contract, combination in the form of trust or otherwise, or conspiracy, in restraint of trade or commerce," 15 U.S.C. § 1, an act that would "monopolize, or attempt to monopolize, or combine or conspire with any other person or persons, to monopolize any part of the trade or commerce among the several States, or with foreign nations ," 15 U.S.C. § 2, or an acquisition of stock of another company whose effect "may be substantially to lessen competition, or to tend to create a monopoly,” 15 U.S.C. § 18. In determining whether a joint venture constitutes a violation, courts will look to factors including risk-sharing and integration of activities. Ilene Knable Gotts, Health Care Joint Ventures and the Antitrust laws: A Guardedly Optimistic Prognosis, $10 \mathrm{~J}$. Contemp. Health L. \& Pol'y 169, 173-75 (1994) (citing cases).
} 
The December edition of the Economist, entitled “The world in 2013" had a notation on "The Fall of the Universal Bank." "The writer suggests that the large banks, such as Citibank and others will shrink. "The power of universal banks will be eroded by market forces. . . In 2013 most universal banks will continue to narrow their focus." 62 It is recognized that banks have moved too closely towards "transaction banking" and too further away from "relationship banking," that is intermediation and servicing lenders. Translated into legal terms there was too strong a movement toward market fund raising and trading on the institutional BHC account, and too little intermediation--deposit money-raising and contract lending. ${ }^{63}$ Banks were designed to intermediate between savers and borrowers. They were not designed to trade in the savers' money and increase the rewards to the traders and their managers. These rewards belong to the savers- not to the traders.

\section{Conclusion}

This Article does not offer a detailed blueprint of restructuring BHCs. Neither does it suggest that market discipline alone can control occasional but horrendous violations and risk-taking by BHCs.

However, while BHCs are shrinking, they are not restructuring. ${ }^{64}$ We need combined controls, including regulatory controls and structural controls. Markets and regulations can be strengthened by the proposed structure to produce a more stable financial system that can be reined-in. Let us add to the structure the right people that may render our system more stable and more fruitful. An effective structure can help attract these persons. Therefore, un-concentrated power is perhaps the most important aspect of restructuring BHCs. It not only reduces control over a very large pool other people's money but also restricts the controllers' choice over the kind of regulation and regulators.

One virtue of converting BHC into a service company is that to limit the BHC's concentrated power, while allowing cooperation and interaction among the different financial services. It would also reduce if not eliminate the inherent conflict of interest that BHCs pose when trading for the Institutional account. This restructure will eliminate the need for name rules including the Volker rule but may require changes in the antitrust laws. To be sure, management of the service company can continue to benefit some shops in the mall rather than others. It can continue to negotiate benefits that are too high for some that do not deserve the rewards, and discriminate against others. But its power to do

\footnotetext{
${ }^{62}$ Lionel Barber, at 142

${ }^{63} \mathrm{Id}$.

${ }^{64}$ Todd Karpovich; Daily Record Business Writer, The Daily Record Co. The Daily Record (Baltimore, MD.), August 15, 2000, Tuesday. First Union, $6^{\text {th }}$ largest bank holding company is shrinking by cutting out jobs. The bank was taking $\$ 3.7$ billion charges in debt and severance packages. . . . Bank of America spokeswoman ... said Maryland will be affected by the cuts. . "Every state in our franchise is going to be affected," Earlier this month, Bank of America announced that William Couper was taking over as president of Bank of America Greater Washington, after serving as president of the Baltimore region. John Morton III, the bank's Mid-Atlantic president, took over Couper's position as president of Bank of America Greater Baltimore.
} 
so will be more limited. Regulation and market ownership of the particular former subsidiaries are likely to induce the services to follow the market and regulatory judgment and refocus on justifiable services.

\section{Who might wish to follow this model?}

There are prominent leaders in the large banking community that advocate breaking up the large banks. They find it difficult to do, as the Citi's experience has been showing and reported. ${ }^{65}$ Legal, structural, and personal objections have added problems. So have power and personal egos. Nonetheless, there are counter-pressures. As Wall Street Journal reported, Investors have sought to split J.P. Morgan top posts with the support of the employees' inion. ${ }^{66}$

Different promoters might be attracted to the new structure. Perhaps a manager of a current BHC, who seeks a fresh structure, ability to control risk better, and desires to attract investors. To be sure, such a manager may hope for a strong position as well as assured better rewards. With the restructure, a manager may indeed start in a position at many of the more promising and profitable financial shops. There is no reason why the shops would not appoint strong candidates, who commit to their success.

The restructure would create additional positions on boards and hopefully attract able directors. Retention of power but distribution of burdens may be attractive to a current leader of a large BHC. An opportunity of leading the way in a bold step may also be a drawing card, especially if the restructure is supported by at least some regulators, such as the FDIC, and some legislators as well. The proliferation of boards and directors may raise costs. However, the costs might be contained by the need to show profits to the markets.

Another group of potential promoters is large funds that may find the structure more attractive and in some cases more familiar. These can include banks or broker-dealers or entrepreneurs or private equity funds who might be interested in acquiring and designing structures which are similar to the one proposed in this Article.

Lionel Barber's of The Economist has predicted a similar process. "In 2013, money and talent will go elsewhere" marking the beginning of the end of the universal bank. ${ }^{67}$ It seems that the bank regulators have woken up. There is a "raging debate over the risk big lenders pose," Wall Street Journal reported. The Federal Reserve board has told a large bank holding company "not to pursue more major deals." 68 Even if this is not a regulatory command it could be a mild suggestion that may go a long way. In fact, some BHC are reducing their size as a measure of cost-cutting. ${ }^{69}$ And investors seek to split BHC

\footnotetext{
65 WS Journal Feb. 21, 2013 C1, C2.

${ }^{66} \mathrm{Id}$. at C3.

${ }^{67}$ Lionel Barber, at 145.

${ }^{68}$ WALL Street J. December 12, 2012 at C1-C2.

${ }^{69}$ Barclays I Set to Join Cost-Cutting Crowd, WALL Street J. December 13, 2012. at C8.
} 
management. ${ }^{70}$ And yet, the tangle that was created in years cannot be untangled in a short time. ${ }^{71}$ It took time to develop these giants and it will take time to restructure them. But it seems that the first steps have already being taken.

${ }^{70}$ Investors Seek to Split J.P. Morgan Top Posts, WALL Street J. February 21, 2013. at C3

${ }^{71}$ Susan Kapner, Citi Set in Stone? Looking Like It, Financial Giants deflect Breakup Talk, WALL Street Journal, February 21, 2013, at C1-C2. 